\title{
Synthesis, Characterization and Antimicrobial Activity of Schiff Base (E)-N-(4-(2-Hydroxybenzylideneamino) Phenylsulfonyl) Acetamide Metal Complexes
}

\author{
Ahmad Sabry Abu-Khadra ${ }^{1}$, Rabie Saad Farag2, Alaa El-Dine Mokhtar Abdel-Hady ${ }^{3}$ \\ ${ }^{1}$ Department of Basic Science, Faculty of Engineering Science, Sinai University, Arish, Egypt \\ ${ }^{2}$ Department of Chemistry, Faculty of Science, Al-Azhar University, Cairo, Egypt \\ ${ }^{3}$ Department of Pharmaceutical Chemistry, Faculty of Pharmacy, Sinai University, Arish, Egypt \\ Email: *ahmad.sabrry@su.edu.eg
}

Received 14 December 2015; accepted 1 March 2016; published 4 March 2016

Copyright (C) 2016 by authors and Scientific Research Publishing Inc.

This work is licensed under the Creative Commons Attribution International License (CC BY). http://creativecommons.org/licenses/by/4.0/

\section{(c) (i) Open Access}

\begin{abstract}
New series of $\mathrm{Ag}, \mathrm{Cd}(\mathrm{II}), \mathrm{Ce}(\mathrm{III}), \mathrm{Co}(\mathrm{II}), \mathrm{Cr}(\mathrm{III}), \mathrm{Fe}(\mathrm{III}), \mathrm{Ni}(\mathrm{II})$ and $\mathrm{Pb}(\mathrm{II})$ complexes with (E)- $\mathrm{N}$-(4-(2hydroxybenzylideneamino) phenylsulfonyl) $\{$ S.S $\}$ have been synthesized. These compounds have been characterized by different physico-chemical techniques like, melting point, elemental analysis, FT-IR, UV spectroscopy, ${ }^{1}$ H NMR spectroscopy, conductance measurements, magnetic susceptibility and mass spectral analysis. The metal ions concentrations have been determined using inductively coupled plasma mass spectrometry (ICP-MS). Spectroscopic studies suggest coordination most of complexes in a regular octahedral arrangement in 2L:1M molar ratio by two $\mathrm{N}$ azomethine and two $\mathrm{OH}$ phenolic from Schiff base $\{\mathrm{S} . S\}$ in the form of $\left[\mathrm{ML}_{2}\left(\mathrm{H}_{2} \mathrm{O}\right)_{2}\right], M$ metal, L ligand \{S.S\}. Complexes have been screened for their antibacterial \{Gram negative bacteria (Escherichia coli and Pseudomonas aeruginosa)\}, \{Gram positive bacteria (Bacillus subtilis and Sterptococcus pneumoniae)\} and antifungal (Aspergillus fumigates and Candida albicans) showing promising antimicrobial biological activity.
\end{abstract}

\section{Keywords}

Biological Activity, Inductively Coupled Plasma, Synthesis, Sulfacetamide, Transition Metal Complexes

\footnotetext{
${ }^{*}$ Corresponding author.
}

How to cite this paper: Abu-Khadra, A.S., Farag, R.S. and Abdel-Hady, A.M. (2016) Synthesis, Characterization and Antimicrobial Activity of Schiff Base (E)-N-(4-(2-Hydroxybenzylideneamino) Phenylsulfonyl) Acetamide Metal Complexes. American Journal of Analytical Chemistry, 7, 233-245. http://dx.doi.org/10.4236/ajac.2016.73020 


\section{Introduction}

Schiff bases are the compounds containing azomethine group $(-\mathrm{HC}=\mathrm{N}-)$ which were first reported by Hugo Schiff in 1864 and formed by condensation of a primary amine with an active carbonyl compound, and generally take place under acid, base catalysis or with heat [1] [2]. They are important compounds owing to their wide range of biological activities and industrial application; they have been found to posses the pharmacological activities such as anti-malarial [3], anticancer [4], antibacterial, antifungal [5], anti-tubercular [6], and anti-inflammatory [7]. Sulfonamide derivatives have been subjected to intensive studies, where a wide variety of those derivatives have been prepared and used in various biological and pharmacological fields. Schiff bases are derived from sulfonamide derivatives which have been used for numerous biological applications [8] [9]. The usage of $\mathrm{Zn}(\mathrm{II}), \mathrm{Cu}(\mathrm{II}), \mathrm{Ni}(\mathrm{II}), \mathrm{Ce}(\mathrm{III}), \mathrm{Bi}(\mathrm{III}), \mathrm{Cd}(\mathrm{II}), \mathrm{Hg}(\mathrm{II}), \mathrm{Sm}(\mathrm{III})$ and $\mathrm{UO}_{2}$ sulfonamide Schiff base has been reported showing its versatility in coordination chemistry and medicinal chemistry, for examples, cobalt(II), copper(II), nickel(II) and zinc(II) complexes of mercaptothiadiazole-derived from furanyl, thienyl, pyrrolyl, salicylyl and pyridinyl Schiff bases [10], anti-tuberculosis agent and pharmacological activities of sulfonamide copper complexes [11], crystal structure of zinc(II) 2-sulfanilamidopyrimidine [12], sulfamethoxydiazine complexes of copper(II), zinc(II), nickel(II), cadmium(II), chromium(III) and iron(III) [13], disulfamethoxazole diaquo $\mathrm{Ni}(\mathrm{II})$ monohydrate [14], Copper complexes with sulfonamides with pUC18 plasmid and hydrogen peroxide [15], binuclear dioxomolybdenum(VI) chelates involving Schiff bases derived from sulpha drugs and 4benzoyl-3-methyl-1-phenyl-2-pyrazolin-5-one [16], sulfa oxovanadium(IV) complexes involving the O,N-donor environment of pyrazolone-based drug Schiff bases [17], mixed ligand complexes of $\mathrm{Cu}(\mathrm{II}), \mathrm{Ni}(\mathrm{II}), \mathrm{Co}(\mathrm{II})$, $\mathrm{Zn}(\mathrm{II}), \mathrm{Sm}(\mathrm{III})$, and $\mathrm{UO}_{2}(\mathrm{VI})$ with a Schiff Base derived from the sulfamerazine and 2,2'-bipyridine [18]. Currently, several methods are used for the determination of transition metal ions, such as atomic absorption spectroscopy (AAS), inductively coupled plasma atomic emission spectrometry (ICP-AES), inductively coupled plasma mass spectrometry (ICP-MS), and ion chromatography (IC). However, simultaneous multi-element analysis for AAS is impossible, while ICP-AES and ICP-MS instruments are most suitable. ICP-MS is another analytical method to determine elements. It is capable to detect mainly metals and several nonmetals. It has many advantages compared to other elemental analysis techniques such as atomic absorption and emission spectrometry including ICP-AES. The advantages are: 1) it has equal or better detection limits for most elements than Graphite Furnace Atomic Absorption Spectroscopy (GFAAS); 2) it has higher throughput than GFAAS; 3) it can handle both simple and complex matrices with minimum matrix interferences due to the high temperature of ICP source; 4) it has superior detection capability to ICP-AES under the same sample throughput; 5) it has ability to obtain isotropic information [19]. The present work was devoted to elucidating the structures of new series of $\mathrm{Ag}, \mathrm{Cd}(\mathrm{II}), \mathrm{Ce}(\mathrm{III}), \mathrm{Co}(\mathrm{II}), \mathrm{Cr}(\mathrm{III}), \mathrm{Fe}(\mathrm{III}), \mathrm{Ni}(\mathrm{II})$ and $\mathrm{Pb}(\mathrm{II})$ complexes with $(E)-\mathrm{N}$-(4-(2-hydroxybenzylideneamino) phenylsulfonyl) and to check their biological activities.

\section{Experimental}

\subsection{Materials and Methods}

All chemicals and solvents employed in synthesis were of extra-pure grade and used as received without any further purification. Sulfacetamide were obtained as a donated sample from Epico Pharm (Cairo Egypt). Melting points were taken on (BI Bamtead Electothermal) and are uncorrected. TLC was visualized by VL-6-LC, UV lamp. Elemental analysis (C, H, N, S) was carried out at Fisons EA 1108 CHNS Micro analyzer. Metal ions concentrations were measured using ICP-MS Perkin Elmer/Optima 7000 with a Cetax LSX-200 UV laser module. The UV spectra of compounds were recorded by UV-Vis. Spectrophotometer (UV-1700, Shimadzu). Molar conductance measurements were made in DMF at $25^{\circ} \mathrm{C} \pm 5^{\circ} \mathrm{C}$ using a Systronics conductivity bridge model 305. Magnetic susceptibility was measured on powdered samples using the Sherward scientific magnetic susceptibility balance. The diamagnetic corrections were made by Pascal's constant and $\mathrm{Hg}\left[\mathrm{Co}(\mathrm{SCN})_{4}\right]$ was used as the calibrant. Mass spectral analysis were measured using Shimadazu Qp-2010 plus. Infrared spectra were recorded by a Perkin-Elmer FT-IR 1650 spectrophotometer in wave number region $4000-400 \mathrm{~cm}^{-1}$ as $\mathrm{KBr}$ pellet. The ${ }^{1} \mathrm{H}$ NMR spectra were recorded using Mercury-300 bb "NMR 300 MHz", using DMSO-as solvent and tetramethylsilane (TMS) as an internal standard. Antibacterial and antifungal activities measured at The Regional Center for Mycology and Bitechnology, Al-Azhar University, Cairo, Egypt. 


\subsection{Synthesis of Schiff Base}

The compounds were prepared by adding a hot ethanolic solution of Salicylaldehyde ( 0.03 mole) to a hot etanolic solution of (0.03 mole) sulfacetamide with vigorous stirring in 1:1 molar ratio, the reaction refluxed for 3 hours until a yellow precipitate formed, which then washed several times and recrystallized from ethanol, and dried in a vacuum over anhydrous calcium chloride The crude product was further purified by preparative TLC (silica gel) as adsorbent(stationary phase) using Di ethyl ether/EtOAc (1:1) (mobile phase) to afford the desired product.

Melting point was $\left(209^{\circ} \mathrm{C}-211^{\circ} \mathrm{C}\right.$ ) yield $70 \%$, molecular weight (318.07) g per mol $\mathrm{C}_{15} \mathrm{H}_{14} \mathrm{~N}_{2} \mathrm{O}_{4} \mathrm{~S}$, Elemental analysis: calc. (found): C 56.59 (55.97), H 4.43 (4.80), N 8.80 (8.31), S 10.07 (10.01).

\subsection{Synthesis of the Schiff Base Metal Complexes}

Silver complex was prepared by adding a hot water solution of $\mathrm{AgNO}_{3}(0.03$ mole) with vigorous stirring to a hot etanolic solution of (E)- $N$-(4-(2-hydroxybenzylideneamino) phenylsulfonyl) acetamide $\{\mathrm{S} . \mathrm{S}\}$ (0.03 mole) in 1M:1L molar ratio, the remaining complexes were prepared by adding a hot etanolic solution (or distilled water) of metal salt $(0.03$ mole) to a hot etanolic solution of ligand $(0.06$ mole $)$ in $1 \mathrm{M}: 2 \mathrm{~L}$ molar ratio M:L. The reaction refluxed for many hours until a colored (or sometimes white) precipitate formed, which then washed several times and recrystallized from ethanol (or distilled water) then dried in a vacuum over anhydrous calcium chloride.

\subsection{Inductively Coupled Plasma Mass Spectrometry (ICP-MS)}

$5 \mathrm{ml}$ of the internal standard is added to a test tube along with 10 - 500 microliters of metal complex sample (internal standard consists primarily of deionized water, with nitric or hydrochloric acid, and Indium and/or Gallium, depending on the sample type). This mixture is then vortexed for several seconds until it is sufficiently mixed and then loaded onto the auto sampler tray. Operation Parameters for determination of elements by ICPMS are shown in Table 1.

\section{Results and Discussion}

Most of the complexes were colored, stable at room temperature for extended periods, decompose on heating., they are insoluble in water and many common organic solvents (S.S-Co 2:1 complex was readily soluble in water). They are readily soluble in strong coordinating solvents like DMF and DMSO. The analytical data showed that the most of the complexes had stoichiometry of the type $\left[\mathrm{ML}_{2}\left(\mathrm{H}_{2} \mathrm{O}\right)_{2}\right]$, where $\mathrm{M}$ is metal and $\mathrm{L}$ is $\{\mathrm{S} . \mathrm{S}\}$ ligand, except Ag complex forming a silver salt of Schiff base reacts in $1 \mathrm{~L}: 1 \mathrm{M}$ molar ratio (Ag L), as shown in Figure 1 \& Figure 2, and Table 2.

Table 1. Illustrates operation parameters for determination of elements by ICP-MS.

\begin{tabular}{cc}
\hline Parameters & Parameters value \\
\hline Flush pump rate & $1.85 \mathrm{~mL} \cdot \mathrm{min}^{-1}$ \\
Analysis pump rate & $1.85 \mathrm{~mL} \cdot \mathrm{min}^{-1}$ \\
Pump relaxation time & $0 \mathrm{~s}$ \\
RF power & $1350 \mathrm{w}$ \\
Nebulizer flow & $26.0 \mathrm{psi}$ \\
Auxiliary gas & $1.0 \mathrm{lpm}$ \\
Gate 1 & $5 \mathrm{~s}$ \\
Gate 2 & $15 \mathrm{~s}$ \\
Light source & ICAP \\
ICAP view & Axial \\
Replicate numbers & 3 \\
Detection wavelength/nm & Ag 338.289, Cd 228.802, Ce 413.380 Co 238.892, Cr 205.560, Cu 327.393, Ni 221.648, Pb 220.353 \\
\hline
\end{tabular}




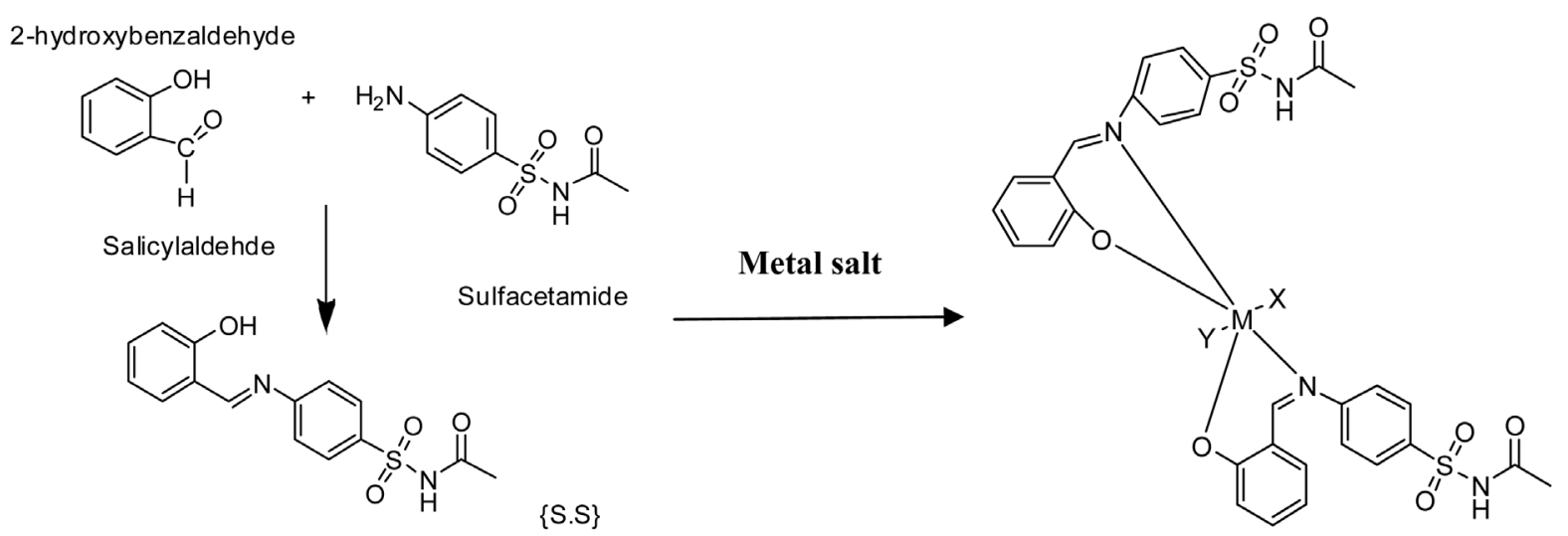

Figure 1. Shows condensation reaction between Salicylaldehyde and Sulfacetamide followed by reaction with metal salt forming the proposed structures of metal complexes, where $\mathrm{M}=\mathrm{Cd}$, Co, Ni or $\mathrm{Pb}\left(\mathrm{X}=\mathrm{Y}=\mathrm{H}_{2} \mathrm{O}\right) ; \mathrm{M}=\mathrm{Cr}\left(\mathrm{X}=\mathrm{H} \mathrm{H}_{2} \mathrm{O}=\mathrm{Cl}\right)$; $\mathrm{M}=\mathrm{Ce}\left(\mathrm{X}=\mathrm{H}_{2} \mathrm{O}, \mathrm{Y}=\mathrm{NO}_{3}\right) ; \mathrm{M}=\mathrm{Fe}(\mathrm{III})\left(\mathrm{X}=\mathrm{Y}=\mathrm{H}_{2} \mathrm{O}\right)$ and the complex is charged $\left[\mathrm{C}_{30} \mathrm{H}_{30} \mathrm{FeN}_{4} \mathrm{O}_{10} \mathrm{~S}_{2}\right]^{3+}\left(\mathrm{NO}_{3}\right)_{3}{ }^{-3} \cdot 3\left(\mathrm{H}_{2} \mathrm{O}\right)$.<smiles>CCCCCN(C(C)=O)S(=O)(=O)c1ccc(/N=C/c2ccccc2O)cc1</smiles>

Figure 2. Shows proposed structure for Ag complex (a silver salt of Schiff base).

Table 2. Analytical and physical data. \{S.S $\}$ (E)- $N$-(4-(2-hydroxybenzylideneamino) phenylsulfonyl.

\begin{tabular}{|c|c|c|c|c|c|c|}
\hline \multirow{2}{*}{$\begin{array}{l}\text { Compds. } \\
\text { symbol }\end{array}$} & \multicolumn{2}{|c|}{ Reactants } & \multicolumn{4}{|c|}{ Products } \\
\hline & Ligand & Metal salts & Color & M.P ${ }^{\circ} \mathrm{C}$ & Yield (\%) & M.F. (M.wt) \\
\hline $\begin{array}{l}\text { S.S-Ag } \\
1: 1\end{array}$ & S.S & $\mathrm{AgNO}_{3}$ & Black & $>300$ & 77.2 & $\begin{array}{l}\mathrm{C}_{15} \mathrm{H}_{13} \mathrm{AgN}_{2} \mathrm{O}_{4} \mathrm{~S} \\
(425.21)\end{array}$ \\
\hline $\begin{array}{l}\text { S.S-Cd } \\
2: 1\end{array}$ & S.S & $3 \mathrm{CdSO}_{4} \cdot 8 \mathrm{H}_{2} \mathrm{O}$ & White & $>300$ & 56.3 & $\begin{array}{l}\mathrm{C}_{30} \mathrm{H}_{30} \mathrm{CdN}_{4} \mathrm{O}_{10} \mathrm{~S}_{2} \\
\quad(783.12)\end{array}$ \\
\hline $\begin{array}{l}\text { S.S-Ce } \\
2: 1\end{array}$ & S.S & $\mathrm{Ce}\left(\mathrm{NO}_{3}\right)_{3} \cdot 6 \mathrm{H}_{2} \mathrm{O}$ & Yellow & $>300$ & 55.2 & $\begin{array}{l}\mathrm{C}_{30} \mathrm{H}_{28} \mathrm{CeN}_{5} \mathrm{O}_{12} \mathrm{~S}_{2} \\
\quad(854.82)\end{array}$ \\
\hline $\begin{array}{l}\text { S.S-Co } \\
2: 1\end{array}$ & S.S & $\mathrm{CoCl}_{2} \cdot 6 \mathrm{H}_{2} \mathrm{O}$ & Rose & $>300$ & 81.5 & $\begin{array}{c}\mathrm{C}_{30} \mathrm{H}_{30} \mathrm{CoN}_{4} \mathrm{O}_{10} \mathrm{~S}_{2} \\
(729.64)\end{array}$ \\
\hline $\begin{array}{l}\text { S.S-Cr } \\
2-1\end{array}$ & S.S & $\mathrm{CrCl}_{3} \cdot 6 \mathrm{H}_{2} \mathrm{O}$ & Green & $201-203$ & 83.8 & $\begin{array}{c}\mathrm{C}_{30} \mathrm{H}_{28} \mathrm{ClCrN}_{4} \mathrm{O}_{9} \mathrm{~S}_{2} \\
(740.14)\end{array}$ \\
\hline $\begin{array}{l}\text { S.S-Fe(III) } \\
2-1\end{array}$ & S.S & $\mathrm{Fe}\left(\mathrm{NO}_{3}\right)_{3} \cdot 9 \mathrm{H}_{2} \mathrm{O}$ & Yellow & $>300$ & 71.8 & $\begin{array}{c}{\left[\mathrm{C}_{30} \mathrm{H}_{30} \mathrm{FeN}_{4} \mathrm{O}_{10} \mathrm{~S}_{2}\right]^{3+}\left(\mathrm{NO}_{3}\right)_{3}{ }^{3} \cdot 3\left(\mathrm{H}_{2} \mathrm{O}\right)} \\
(966.62)\end{array}$ \\
\hline $\begin{array}{l}\text { S.S-Ni } \\
\text { 2:1 }\end{array}$ & S.S & $\mathrm{NiSO}_{4} \cdot 6 \mathrm{H}_{2} \mathrm{O}$ & White & $>300$ & 52.6 & $\begin{array}{c}\mathrm{C}_{30} \mathrm{H}_{30} \mathrm{NiN}_{4} \mathrm{O}_{10} \mathrm{~S}_{2} \\
(729.40)\end{array}$ \\
\hline $\begin{array}{l}\text { S.S-Pb } \\
2: 1\end{array}$ & S.S & $\mathrm{Pb}\left(\mathrm{NO}_{3}\right)_{2}$ & White & $221 \quad 223$ & 85.5 & $\begin{array}{c}\mathrm{C}_{30} \mathrm{H}_{30} \mathrm{PbN}_{4} \mathrm{O}_{10} \mathrm{~S}_{2} \\
\quad(877.91)\end{array}$ \\
\hline
\end{tabular}

According to pervious data the reaction of forming Schiff base and complexes can be expressed as shown in Figure 1.

In case of Ag complex the proposed structure is as shown in Figure 2.

\subsection{Elemental Analyses of the Complexes}

The results of elemental analyses as shown in Table 3, which are in a good agreement with those required by the proposed formula (calculated). Inductively coupled plasma (ICP-MS) technique plays an important role in confirming the structures of the complexes, by determining metal ion concentration. The metal percentages of newly synthesized Schiff base metal complexes which are shown in Table 3, give a good agreement with the proposed formula (calculated), and confirm binding of the metal ion to ligand sites. 
Table 3. Elemental analysis of the complexes Calcd./found.

\begin{tabular}{|c|c|c|c|c|c|}
\hline Compd. Symbol & $\mathrm{C} \%$ & $\mathrm{H} \%$ & N\% & $\mathrm{S} \%$ & M \% (ICP) \\
\hline S.S-Ag & 42.37 & 3.08 & 6.59 & 7.54 & 25.37 \\
\hline $1: 1$ & 42.71 & 3.05 & 6.48 & 7.68 & 25.42 \\
\hline S.S-Cd & 46.01 & 3.86 & 7.15 & 8.19 & 14.35 \\
\hline $2: 1$ & 46.22 & 3.46 & 7.11 & 8.13 & 14.23 \\
\hline S.S-Ce & 42.15 & 3.30 & 8.19 & 7.50 & 16.39 \\
\hline $2: 1$ & 42.41 & 3.46 & 8.23 & 7.72 & 16.32 \\
\hline S.S-Co & 49.38 & 4.14 & 7.68 & 8.79 & 8.08 \\
\hline $2: 1$ & 49.32 & 4.08 & 7.69 & 8.82 & 8.13 \\
\hline S.S-Cr & 48.68 & 3. 81 & 7.57 & 8.66 & 7.03 \\
\hline $2-1$ & 48.75 & 3.78 & 7.64 & 8.72 & 7.12 \\
\hline S.S-Fe(III) & 37.28 & 3.75 & 10.14 & 6.63 & 5.78 \\
\hline $2-1$ & 37.11 & 3.70 & 10.12 & 6.72 & 5.86 \\
\hline S.S-Ni & 49.40 & 4.15 & 7.68 & 8.79 & 8.05 \\
\hline 2:1 & 49.53 & 3.97 & 7.73 & 8.63 & 8.12 \\
\hline S.S-Pb & 41.04 & 3.44 & 6.38 & 7.30 & 23.60 \\
\hline 2:1 & 41.47 & 3.27 & 6.45 & 7.36 & 23.83 \\
\hline
\end{tabular}

\subsection{IR Spectral Studies}

Preliminary identification regarding the formation of Schiff base compound were obtained from the absence of IR bands characteristic for amino group of aryl amine and the carbonyl group of aldehyde. This is further confirmed by the appearance of a new band characteristic of $v \mathrm{C}=\mathrm{N}$ [20] [21]. As shown in Figure 3. The IR spectrum of Schiff base $\{\mathrm{S} . \mathrm{S}\}$ exhibits five potential donor sites, oxygen of the phenolic group $(\mathrm{OH})$, nitrogen of the azomethine group $(\mathrm{C}=\mathrm{N})$, sulfonamide oxygen $\left(\mathrm{SO}_{2}\right)$, nitrogen of secondary amine $(\mathrm{NH})$ and $\mathrm{O}$ acetamido (carbonyl group) (C=O). The $\mathrm{SO}_{2}, \mathrm{C}=\mathrm{O}$, and $\mathrm{NH}$ bands nearly not changed indicating they are not involved in coordination., except Ag complex where its $\mathrm{NH}$ band has big change $3283 \mathrm{~cm}^{-1}$ compared to ligand $3379 \mathrm{~cm}^{-1}$ indicating involvement of this group in coordination, the other bands in Ag complex nearly not changed. A broad band at $3483 \mathrm{~cm}^{-1}$ characteristic to the stretching vibrations of phenolic O-H group, in the free ligand, the disappearance of this peak in the spectra of most complexes indicates the de-protonation of phenol proton prior to coordination [22]. The band at $1544 \mathrm{~cm}^{-1}$ in the ligand may be assigned as $v \mathrm{C}=\mathrm{N}$ stretching vibration of the azomethine group which already shifted to higher frequencies in most complexes suggesting that this group is involved in the coordination with metal [23]. A sharp peaks around $1647 \mathrm{~cm}^{-1}$ is due to $\mathrm{C}=\mathrm{O}$ stretching vibrations. The bands around $1315 \mathrm{~cm}^{-1}$ and $1145 \mathrm{~cm}^{-1}$ represent the asymmetric and symmetric stretching frequencies of the sulfonyl group ( $\mathrm{S}=\mathrm{O}$ str) respectively [24]. The hydrated complexes exhibited an IR band at approximately br $3450 \mathrm{~cm}^{-1}$ range due to $v\left(\mathrm{H}_{2} \mathrm{O}\right)$, suggesting the coordination of water molecules in most of the complexes. The coordination of oxygen of the phenolic group $(\mathrm{OH})$ and nitrogen of the azomethine group $(\mathrm{C}=\mathrm{N})$ atoms is further supported by appearance of two non ligand bands at $539-555 \mathrm{~cm}^{-1}$ and $448-467 \mathrm{~cm}^{-1}$ due to $v \mathbf{M} \_\mathrm{N}$ and $v \mathbf{M} \_$O respectively, studies on the stretching vibrations of these bonds are important in elucidating the structure of the complex, [25]. In case of Ag complex contain one band at 548 confirming coordination of $\mathrm{NH}$ only. Other bands like $v \mathrm{C}-\mathrm{H}$ Ar appears around $2950 \mathrm{~cm}^{-1}$ and $v \mathrm{C}-\mathrm{H} \mathrm{Al}$ appears around $2800 \mathrm{~cm}^{-1}$, another bands such as $\mathrm{C}=\mathrm{C}$ appears around $1500 \mathrm{~cm}^{-1}$ [26]. These bands are illustrated in Table 4 .

\subsection{Molar Conductivity Measurements}

By using the relation $\Lambda \mathrm{m}=\mathrm{K} / \mathrm{C}$, the molar conductance of the complexes $(\Lambda \mathrm{m})$ can be calculated, where $\mathrm{C}$ is the molar concentration of the metal complex solutions, $\mathrm{K}=$ specific conductivity of the complex. The chelates were dissolved in DMF, the molar conductivities of $10^{-4} \mathrm{M}$ of their solutions at $25^{\circ} \mathrm{C} \pm 2{ }^{\circ} \mathrm{C}$ were measured. Table 5 shows the low molar conductivity values of all complexes $\left(\Lambda_{\mathrm{m}}=6.2-27.43 \Omega^{-1} \cdot \mathrm{mol}^{-1} \cdot \mathrm{cm}^{2}\right)$ indicates that these complexes are non-electrolytes [27]. Except Fe(III) complex, it has high molar conductance of 195.97 $\Omega^{-1} \cdot \mathrm{mol}^{-1} \cdot \mathrm{cm}^{2}$ indicating electrolytic nature of the complex [28]. 


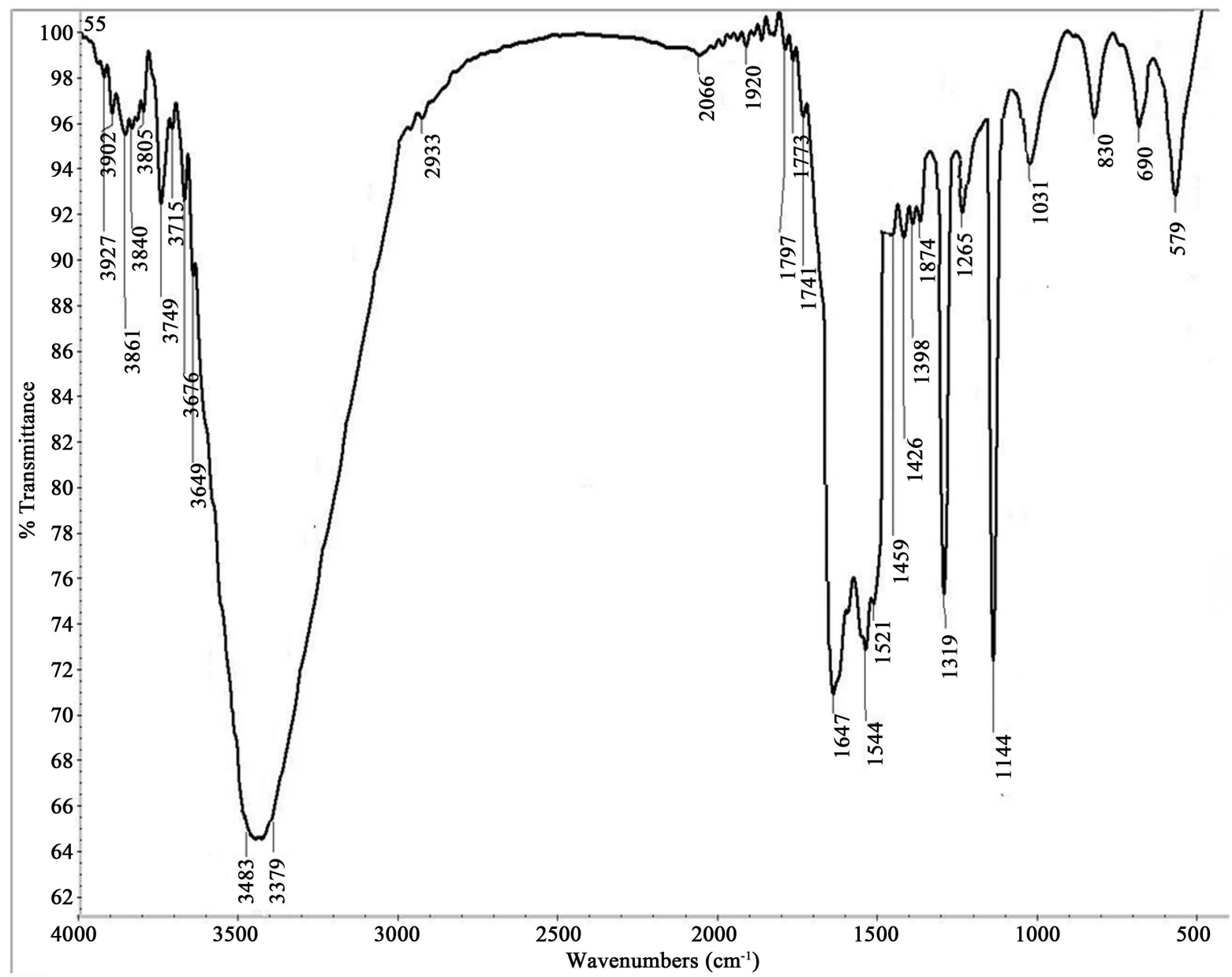

Figure 3. Shows Infra red spectrum of Schiff base $\{$ S.S $\}$ ligand.

Table 4. IR spectral studies.

\begin{tabular}{|c|c|c|c|c|c|c|c|c|}
\hline Compounds/Bands & $v \mathrm{H}_{2} \mathrm{O}$ br & $v \mathrm{~N}-\mathrm{H}$ & $v \mathrm{C}=\mathrm{O}$ & $v \mathrm{C}=\mathrm{N}$ & $v \mathrm{SO}_{2} \mathrm{as}$ & $v \mathrm{SO}_{2} \mathrm{Sym}$ & $v \mathrm{M}-\mathrm{N}$ & $v \mathrm{M}-\mathrm{O}$ \\
\hline S.S & $v \mathrm{O}-\mathrm{H}$ br at 3483 & 3379 & 1647 & 1544 & 1319 & 1144 & - & - \\
\hline $\begin{array}{c}\text { S.S-Ag } \\
1: 1\end{array}$ & $v \mathrm{O}-\mathrm{H}$ br at 3480 & 3283 & 1643 & 1542 & 1313 & 1141 & 549 & - \\
\hline $\begin{array}{c}\text { S.S-Cd } \\
2: 1\end{array}$ & 3448 & 3376 & 1642 & 1599 & 1311 & 1142 & 550 & 454 \\
\hline $\begin{array}{c}\text { S.S-Ce } \\
2: 1\end{array}$ & 3450 & 3388 & 1648 & 1578 & 1319 & 1144 & 554 & 449 \\
\hline $\begin{array}{c}\text { S.S-Co } \\
2: 1\end{array}$ & 3451 & 3381 & 1649 & 1578 & 1320 & 1150 & 554 & 460 \\
\hline $\begin{array}{c}\text { S.S-Cr } \\
2-1\end{array}$ & 3447 & 3382 & 1644 & 1596 & 1310 & 1150 & 541 & 456 \\
\hline $\begin{array}{c}\text { S.S-Fe(III) } \\
2-1\end{array}$ & 3450 & 3385 & 1648 & 1591 & 1315 & 1149 & 550 & 467 \\
\hline $\begin{array}{c}\text { S.S-Ni } \\
2: 1\end{array}$ & 3444 & 3384 & 1640 & 1584 & 1321 & 1148 & 555 & 454 \\
\hline $\begin{array}{c}\text { S.S-Pb } \\
2: 1\end{array}$ & 3449 & 3374 & 1641 & 1594 & 1314 & 1148 & 539 & 448 \\
\hline
\end{tabular}


Table 5. The UV-Visible spectra, molar conductance and magnetic moment metal complexes.

\begin{tabular}{|c|c|c|c|c|}
\hline $\begin{array}{l}\text { Compds. } \\
\text { Symbol }\end{array}$ & $\lambda \max n m$ & $\Lambda \mathrm{m} \cdot \Omega^{-1} \cdot \mathrm{mol}^{-1} \cdot \mathrm{cm}^{2}$ & $\mu$ eff. (B.M.) & Geometry \\
\hline S.S & 361, 324, 271, 259, 229, 213. & - & - & - \\
\hline $\begin{array}{l}\text { S.S-Ag } \\
1: 1\end{array}$ & $\begin{array}{c}\text { 717, 503, 454, 334, } 296 \\
\text { 269, 229, } 208 .\end{array}$ & 7.7 & Diamagnetic & Planner \\
\hline $\begin{array}{l}\text { S.S-Cd } \\
2: 1\end{array}$ & $\begin{array}{c}\text { 633, 538, 457, 342, 283, } \\
255,229,215 .\end{array}$ & 22.1 & Diamagnetic & Octahedral \\
\hline $\begin{array}{l}\text { S.S-Ce } \\
2: 1\end{array}$ & 601, 522, 454,347, 284, 259, 227, 213. & 8.57 & 2.98 & Octahedral \\
\hline $\begin{array}{l}\text { S.S-Co } \\
2: 1\end{array}$ & $\begin{array}{c}\text { 640, 573, 496, 451, 366, } 311 \\
\text { 281, 259, 225, } 213 .\end{array}$ & 11.8 & 4.58 & Octahedral \\
\hline $\begin{array}{l}\text { S.S-Cr } \\
2-1\end{array}$ & 742, 633, 538, 459,418, 365, 303. 286, 253, 223, 213. & 6.2 & 3.76 & Octahedral \\
\hline $\begin{array}{l}\text { S.S-Fe(III) } \\
2-1\end{array}$ & 665, 544, 449, 366, 313, 276, 259, 224, 214. & 195.97 & 5.77 & Octahedral \\
\hline $\begin{array}{l}\text { S.S-Ni } \\
2: 1\end{array}$ & 698, 633, 538, 460, 363, 292.255, 229, 215. & 9.39 & 3.22 & Octahedral \\
\hline $\begin{array}{l}\text { S.S-Pb } \\
2: 1\end{array}$ & 725, 662, 576, 452, 345, 296, 263, 232, 214. & 27.43 & Diamagnetic & Octahedral \\
\hline
\end{tabular}

\subsection{Magnetic Susceptibility Measurements}

The magnetic moments values, $\mu$ eff of the Ce(III)complex is 2.98 B.M., being consistent with mononuclear complex and free from antiferromagnetism [29]. Co(II) and Ni(II) complexes have magnetic moment values 4.58 B.M. and 3.22 B.M. respectively which agrees well with the expected value for a high-spin Co(II) ion in an octahedral environment [30]. The Cr complex show a magnetic moment 3.76 B.M. corresponding to 3 unpaired electrons, which is approximately equal to a spin-only value [31]. The observed magnetic moments of Fe(III), is 5.77 B.M. Thus, the complexes formed have octahedral geometry involving $\mathrm{d}^{2} \mathrm{sp}^{3}$ hybridization in the Fe ions [32]. On the basis of analytical, conductance and spectral data and the magnetic moments values, $\mu$ eff, complexes were assigned an octahedral geometry except Ag complex was planner.

\subsection{Electronic Spectra}

The electronic spectra for all the compounds were obtained in DMSO solutions. The UV-VIS spectra of the ligand $\left\{S . S\right.$, showed many bands at $271 \mathrm{~nm}$, and $324 \mathrm{~nm}$, assigned to $\pi \rightarrow \pi^{*}$ (phenyl group nm, $\mathrm{C}=\mathrm{C}$ ), $\mathrm{n} \rightarrow \pi^{*}$ transitions within the molecule $(\mathrm{C}=\mathrm{O})$ respectively [33]. $\mathrm{SO}_{2}$ group merge to form a single strong absorption band around 260. Most bands were slightly shifted to blue or red regions in all complexes indicating coordination of the ligand to the metal. The bands around 450 is characteristic for the ligand to metal charge transfer LMCT) from the nitrogen atom to the transition metal centre. When the NH-proton is lost, the first band is affected while the coordination affects the other bands as well, this observed in Ag complex. The new bands were observed in the visible region for the complexes due to $\mathrm{d} \rightarrow \mathrm{d}$ transitions. The Ag and Cd show no $\mathrm{d}$ - $\mathrm{d}$ bands as is expected for a $\mathrm{d}^{10}$ system and was found to be diamagnetic in nature. Also the $\mathrm{Pb}$, complexes contain only paired electrons and was found to be diamagnetic in nature. The electronic spectrum of the Co(II) complex shows two strong bands at 640 and $496 \mathrm{~nm}$ which are assigned to ${ }^{4} \mathrm{~T}_{1 \mathrm{~g}} \rightarrow{ }^{4} \mathrm{~A}_{2 \mathrm{~g}}(\mathrm{~F})(\mathrm{v} 2)$ and ${ }^{4} \mathrm{~T}_{1 \mathrm{~g}}(\mathrm{~F}) \rightarrow{ }^{4} \mathrm{~T}_{1 \mathrm{~g}}(\mathrm{P})(\mathrm{v} 3)$ transitions, respectively, as expected for an octahedral Co(II) complexes. The electronic spectrum of the Ni(II) complex exhibits three bands at 698,633 and $460 \mathrm{~nm}$ attributable to ${ }^{3} \mathrm{~A}_{2 \mathrm{~g}}(\mathrm{~F}) \rightarrow{ }^{3} \mathrm{~T}_{2 \mathrm{~g}}(\mathrm{~F})(\mathrm{v} 1),{ }^{3} \mathrm{~A}_{2 \mathrm{~g}}(\mathrm{~F}) \rightarrow{ }^{3} \mathrm{~T}_{1 \mathrm{~g}}(\mathrm{~F})$ (v2) and ${ }^{3} \mathrm{~A}_{2 g}(\mathrm{~F}) \rightarrow{ }^{3} \mathrm{~T}_{1 \mathrm{~g}}(\mathrm{P})(\mathrm{v} 3)$ transitions, respectively, for an octahedral Ni(II) complex [34] [35]. Spectrum of Iron (III) complex exhibited three bands in the region 366 - $665 \mathrm{~nm}$ that are assignable for ${ }^{6} \mathrm{~A}_{1 \mathrm{~g}} \rightarrow{ }^{4} \mathrm{~T}_{1 \mathrm{~g}}{ }^{6} \mathrm{~A}_{1 \mathrm{~g}}$ $\rightarrow{ }^{4} \mathrm{E}_{\mathrm{g}},{ }^{4} \mathrm{~A}_{1 \mathrm{~g}}(\mathrm{G})$ and ${ }^{6} \mathrm{~A}_{1 \mathrm{~g}} \rightarrow{ }^{4} \mathrm{E}_{\mathrm{g}}$ (D) transitions which can be assigned to transition characteristic of octahedral structure [36]. Cerium(III) complex show a new absorption band at $454 \mathrm{~nm}$ which may be related to metal-ligand charge transfer excitations The complexes have a coordination number 6 and may exist in octahedral geometries [37]. Chromium(III) complex show three bands 538, 459 and $253 \mathrm{~nm}$ similar to those observed for six coordinate chromium complexes [38]. 


\subsection{Mass Spectra Analysis}

The mass spectra of complexes are given in Table 6 as representative examples. The molecular ion peaks are in good agreement with their empirical as indicated from elemental analyses. The other peaks represent fragments of the molecular ions.

\section{7. ${ }^{1} \mathrm{H}$ NMR Spectra}

${ }^{1} \mathrm{H}$ NMR for ligand $\{\mathrm{S} . \mathrm{S}\}$ is shown in Figure 4 and the diamagnetic complexes (Ag, Cd, and Pb complexes) are shown in Table 7. All the protons were found as expected in the spectra of compounds. The spectra of the diamagnetic complexes were examined in comparison with $\{$ S.S $\}$, ligand. The diamagnetic complexes and ligand give a duplet signals in the region $6.54-7.88$ ppm (d) for the aromatic protons. Singlet peaks appeared in the re-

Table 6. Mass spectral data of the compounds.

\begin{tabular}{|c|c|c|}
\hline Compound symbol & Molecular ion $\left(\mathrm{M}^{+}\right)$peak at $m / z$ & Relative intensity (\%) \\
\hline S.S & $\begin{array}{l}\mathrm{C}_{15} \mathrm{H}_{14} \mathrm{~N}_{2} \mathrm{O}_{4} \mathrm{~S} \\
\quad(318.07)\end{array}$ & 73.5 \\
\hline $\begin{array}{l}\text { S.S-Ag } \\
1: 1\end{array}$ & $\begin{array}{l}\mathrm{C}_{15} \mathrm{H}_{13} \mathrm{AgN}_{2} \mathrm{O}_{4} \mathrm{~S} \\
\quad(425.21)\end{array}$ & 88.4 \\
\hline $\begin{array}{l}\text { S.S-Cd } \\
2: 1\end{array}$ & $\begin{array}{c}\mathrm{C}_{30} \mathrm{H}_{30} \mathrm{CdN}_{4} \mathrm{O}_{10} \mathrm{~S}_{2} \\
\quad(783.12)\end{array}$ & 61.1 \\
\hline $\begin{array}{l}\text { S.S-Ce } \\
2: 1\end{array}$ & $\begin{array}{c}\mathrm{C}_{30} \mathrm{H}_{28} \mathrm{CeN}_{5} \mathrm{O}_{12} \mathrm{~S}_{2} \\
\quad(854.82)\end{array}$ & 66.8 \\
\hline $\begin{array}{l}\text { S.S-Co } \\
2: 1\end{array}$ & $\begin{array}{l}\mathrm{C}_{30} \mathrm{H}_{30} \mathrm{CoN}_{4} \mathrm{O}_{10} \mathrm{~S}_{2} \\
\quad(729.64)\end{array}$ & 86.1 \\
\hline $\begin{array}{l}\text { S.S-Cr } \\
2-1\end{array}$ & $\begin{array}{c}\mathrm{C}_{30} \mathrm{H}_{28} \mathrm{ClCrN}_{4} \mathrm{O}_{9} \mathrm{~S}_{2} \\
(740.14)\end{array}$ & 77.4 \\
\hline $\begin{array}{l}\text { S.S-Fe(III) } \\
2-1\end{array}$ & $\begin{array}{c}{\left[\mathrm{C}_{30} \mathrm{H}_{36} \mathrm{FeN}_{7} \mathrm{O}_{22} \mathrm{~S}_{2}\right]^{3+}\left(\mathrm{NO}_{3}\right)_{3}{ }^{-3} \cdot 3\left(\mathrm{H}_{2} \mathrm{O}\right)} \\
(966.62)\end{array}$ & 82.0 \\
\hline $\begin{array}{l}\text { S.S-Ni } \\
2: 1\end{array}$ & $\begin{array}{l}\mathrm{C}_{30} \mathrm{H}_{30} \mathrm{NiN}_{4} \mathrm{O}_{10} \mathrm{~S}_{2} \\
\quad(729.40)\end{array}$ & 69.9 \\
\hline $\begin{array}{l}\text { S.S-Pb } \\
2: 1\end{array}$ & $\begin{array}{c}\mathrm{C}_{30} \mathrm{H}_{30} \mathrm{PbN}_{4} \mathrm{O}_{10} \mathrm{~S}_{2} \\
\quad(877.91)\end{array}$ & 92.8 \\
\hline
\end{tabular}

Table 7. Proton NMR spectral data of the diamagnetic complexes and Schiff base.

\begin{tabular}{|c|c|}
\hline Compound & Chemical shift, $(\delta)$ ppm \& Assignment \\
\hline$\{\mathrm{S} . \mathrm{S}\}$ & $\begin{array}{c}12.88(\mathrm{~s}, 1 \mathrm{H}, \mathrm{OH}) \\
11.85(\mathrm{~s}, 1 \mathrm{H}, \mathrm{NH}) \\
8.96(\mathrm{~s}, 1 \mathrm{H}, \mathrm{CH}=\mathrm{N}) \\
6.96-7.83(\mathrm{~d}, 8 \mathrm{H}, \mathrm{ArH}) \\
1.68\left(\mathrm{~s}, 3 \mathrm{H}, \mathrm{CH}_{3}\right)\end{array}$ \\
\hline $\begin{array}{c}\text { S.S-Ag } \\
1: 1\end{array}$ & $\begin{array}{c}12.80(\mathrm{~s}, 1 \mathrm{H}, \mathrm{OH}) \\
\mathrm{NH} \text { absent } \\
8.92(\mathrm{~s}, 1 \mathrm{H}, \mathrm{CH}=\mathrm{N}) \\
6.82-7.71(\mathrm{~d}, 8 \mathrm{H}, \mathrm{ArH}) \\
1.61\left(\mathrm{~s}, 3 \mathrm{H}, \mathrm{CH}_{3}\right)\end{array}$ \\
\hline $\begin{array}{c}\text { S.S-Cd } \\
2-1\end{array}$ & $\begin{array}{c}\text { OH absent } \\
11.89(\mathrm{~s}, 2 \mathrm{H}, \mathrm{NH}) \\
8.53(\mathrm{~s}, 2 \mathrm{H}, \mathrm{CH}=\mathrm{N}) \\
6.69-7.88(\mathrm{~d}, 16 \mathrm{H}, \mathrm{ArH}) \\
1.70\left(\mathrm{~s}, 6 \mathrm{H}, 2 \mathrm{CH}_{3}\right)\end{array}$ \\
\hline $\begin{array}{c}\text { S.S-Pb } \\
2: 1\end{array}$ & $\begin{array}{c}\text { OH absent } \\
11.82(\mathrm{~s}, 2 \mathrm{H}, \mathrm{NH}) \\
8.40(\mathrm{~s}, 2 \mathrm{H}, \mathrm{CH}=\mathrm{N}) \\
6.54-7.66(\mathrm{~d}, 16 \mathrm{H}, \mathrm{ArH}) \\
1.62\left(\mathrm{~s}, 6 \mathrm{H}, \mathrm{CH}_{3}\right)\end{array}$ \\
\hline
\end{tabular}


AhmadSabry-55 -DMSO-H

Archive directory: /export/home/vnmr1/vnmrsys/data

Sample directory: DD5mm test_12Mar 2014-21:34:40

File: PROTON

Pulse Sequence: s2pul

Solvent: DMSO

Temp. 30.0 C/303.1 k

Mercury-300BB "NMR300"

Relax. delay $1.000 \mathrm{sec}$

Pulse 45.0 degrees

Acq. time $4.853 \mathrm{sec}$

Width $6600.7 \mathrm{~Hz}$

7 repetitions

OBSERVE H1, $300.0687865 \mathrm{MHz}$

DATA PROCESSING

FT size 65536

Total time $5 \mathrm{~min}, 16 \mathrm{sec}$

Date: Aug 52014

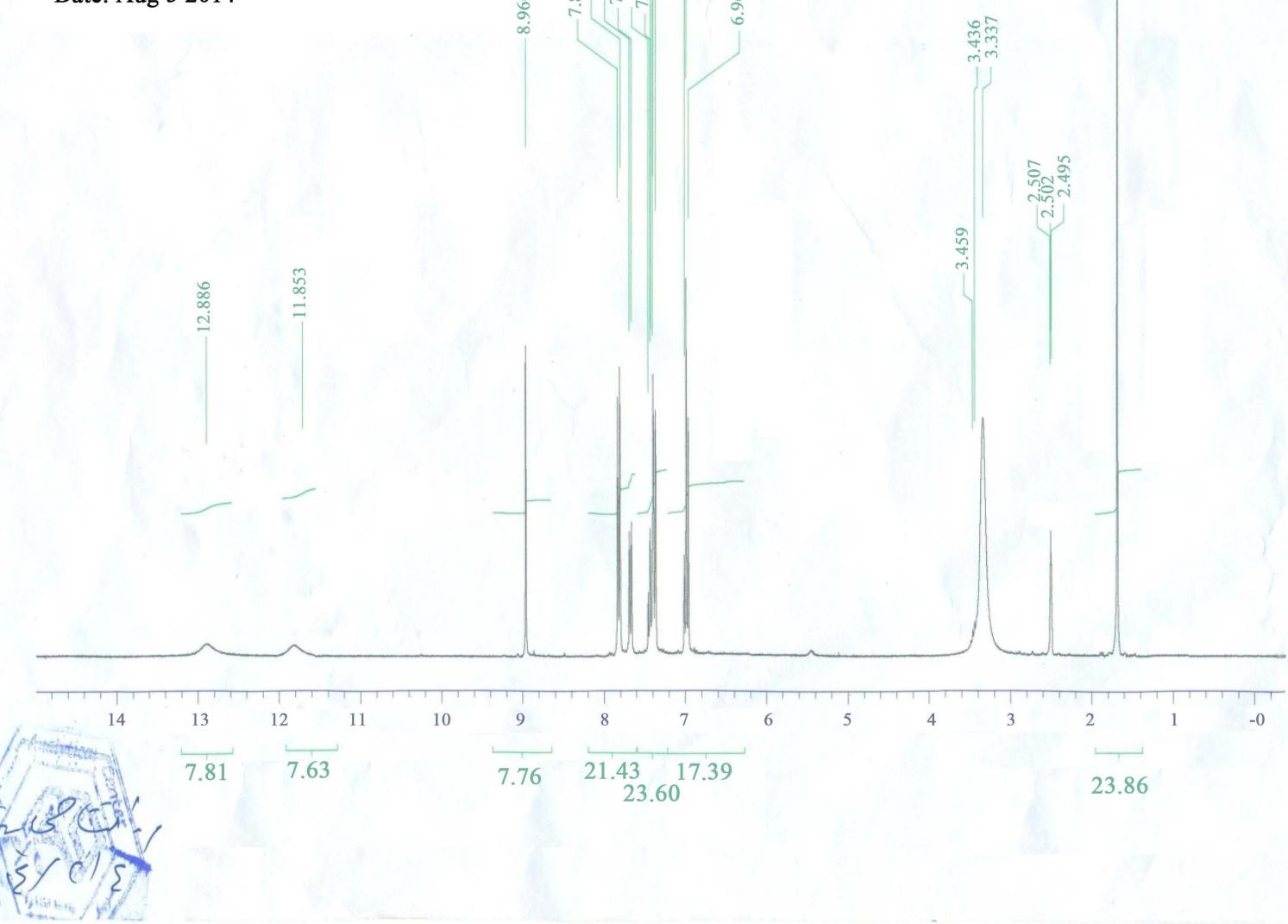

Figure 4. Shows ${ }^{1}$ H NMR spectrum of Schiff base $\{$ S.S $\}$ ligand.

gion of $1.61-1.70 \mathrm{ppm}$ were attributed to the methyl group. The N-H proton give a singlet signals in the region 11.82 - 11.89 ppm (s) which nearly not changed compared to ligand, this indicate NH group is not involved in the coordination of $\mathrm{Cd}$ and $\mathrm{Pb}$ complexes, but the Ag complex we found N-H proton disappeared which confirm participating of this group in the coordination, by losing H proton. Signals for the methine protons of the azomethine group, were observed between 8.96 and $8.40 \mathrm{ppm}$, the coordination of azomethine nitrogen is confirmed by down field shift in $\mathrm{Cd}$ and $\mathrm{Pb}$ complexes, also $\mathrm{OH}$ appear in ligand at $12.88 \mathrm{ppm}$ but disappear in $\mathrm{Cd}$ and $\mathrm{Pb}$ complexes ensure coordination of phenolic oxygen to metal ion in $\mathrm{Cd}$ and $\mathrm{Pb}$ complexes, These numbers of protons results give a good agreement with CHNS calculated and found results.

\subsection{Biological Activity}

This test was performed using the diffusion agar technique [39]. The sensitivity of a microorganism to antibio- 
tics and other antimicrobial agents was determined by the assay plates, which were incubated at $28^{\circ} \mathrm{C}$ for 2 days (for fungi) and at $37^{\circ} \mathrm{C}$ for 1 day (for bacteria). Most of the tested compounds showed a promising biological activity against different types of Gram-positive, Gram-negative bacteria, and fungi. The data are listed in Table 8 show that $E$. coli was inhibited by all complexes. The importance of this lies in the fact that these complexes could reasonably be used for the treatment of some common diseases caused by E. coli, e.g., septicemia, gastroenteritis, urinary tract infections, and hospital-acquired infections, also this promising activity might have a possible antitumor effect since Gram-negative bacteria are considered a quantitative microbiological method for testing beneficial and important drugs, in both clinical and experimental tumor chemotherapy [40]. The mechanism of action of this complex seems to be connected with the inhibition of phosphomannose isomerase, a key enzyme in the bio-synthesis of yeast cell walls. The biological activity of new silver(I) complexes is potentially important, and are developed not only with wound care in mind but some cases of antibiotic resistance, for example, the treatment of lungs chronically infected with cystic fibrosis, it also have successfully been used for the last 20 years for the prophylaxis [41].

Mean zone of inhibition in $\mathrm{mm} \pm$ Standard beyond well diameter $(6 \mathrm{~mm})(100 \mathrm{ml}$ was tested) produced on a range of clinically pathogenic microorganisms using $(5 \mathrm{mg}$ per $\mathrm{ml}$ ) concentration of tested samples. Results are depicted in Table 8.

Table 8. Biological activity of metal complexes.

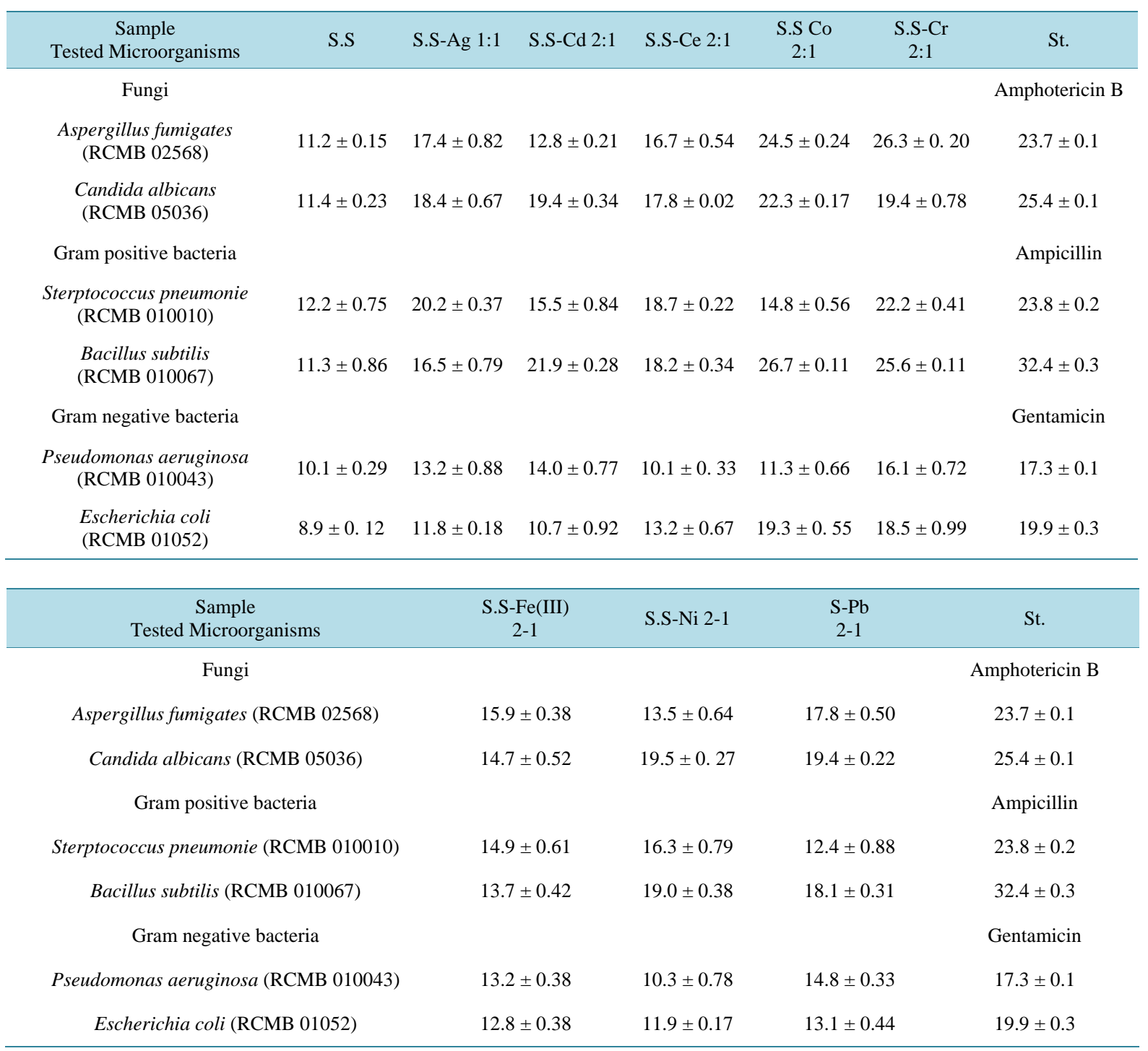




\section{Conclusion}

Based on the above discussions, the prepared Cd(II), Ce(III), $\mathrm{Co}(\mathrm{II}), \mathrm{Cr}(\mathrm{III}), \mathrm{Fe}(\mathrm{III}), \mathrm{Ni}(\mathrm{II})$ and Pb(II) complexes with $(E)-N$-(4-(2-hydroxybenzylideneamino) phenylsulfonyl) showing promising antimicrobial activity and the metal ions concentrations were determined using ICp-MS and gave a good agreement with the formula proposed which involved coordination of metal complexes in a regular octahedral arrangement in 2L:1M molar ratio by two $\mathrm{N}$ azomethine and two $\mathrm{OH}$ phenolic from the Schiff base $\{\mathrm{S} . \mathrm{S}\}$ in the form of $\left[\mathrm{ML}_{2}\left(\mathrm{H}_{2} \mathrm{O}\right)_{2}\right]$ except Ag complex was planner.

\section{References}

[1] Abbas, S.A., Munir, M., Fatima, A., Naheed, S. and Ilyas, Z. (2010) Synthesis, Characterization and Biocidal Studies of Some Transition Metal Complexes Containing Tetra Dentate and Neutral Bi Dentate Schiff Base. ElectronicJournal of Life Science, 1, 37-40.

[2] El-Mossalamy, E.H., Al-Thabati, S.A., Al-Nowalser, F.M. and Al-Sulami, Q.A. (2005) Solvent Effects on the Electronic Absorption Spectra and Dissociation Costants of Some Sulfa Drugs. Communications Faculty of Sciences University of Ankara Series B, 51, 21-30.

[3] Li, Y., Yang, Z.S., Zhang, H., Cao, B.J. and Wang, F.D. (2003) Artemisinin Derivatives Bearing Mannich Base Group Synthesis and Antimalarial Activity. Bioorganic \& Medicinal Chemistry, 11, 4363-4368. http://dx.doi.org/10.1016/S0968-0896(03)00499-1

[4] Villar, R., Encio, I., Migliaccio, M., Gil, M.G. and Martinez-Merino, V. (2004) Synthesis and Cytotoxic Activity of Lipophilic Sulphonamide Derivatives of the Benzo[b]thiophene-1,1-dioxide. Bioorganic \& Medicinal Chemistry, 12, 963968. http://dx.doi.org/10.1016/j.bmc.2003.12.012

[5] Bhat, M.A., Imran, M., Khan, S.A. and Siddiqui, N. (2005) Biological Activities of Sulfonamides. Journal of Pharmaceutical Sciences, 67, 151-159.

[6] Wang, L., Feng, Y., Xue, J. and Li, Y. (2008) Synthesis and Characterization of Novel Porphyrin Schiff Bases. Journal of the Serbian Chemical Society, 73, 1-6. http://dx.doi.org/10.2298/JSC0801001W

[7] Wadher, S.J., Puranik, M.P., Karande, N.A. and Yeole, P.G. (2009) Synthesis and Biological Evaluation of Schiff base of Dapsone and Their Derivative as Antimicrobial Agents. International Journal of PharmTech Research, 1, 22-33.

[8] Hadi, J.S., Alsalami, B.K. and Essa, A.H. (2009) Synthesis, Spectroscopic Characterization and Theoretical Study of Schiff Bases Derived from Phenylsulfonylamide. Journal of Scientific Research, 3, 563-568.

[9] Melagraki, G., Afantitis, A., Sarimveies, H., Markopoulou, O.L. and Supuran, C.T. (2006) A Novel QSAR Model for Modeling and Predicting Induction of Apoptosis by 4-Aryl-4H-chromenes. Bioorganic \& Medicinal Chemistry, 14, 1108-1114. http://dx.doi.org/10.1016/j.bmc.2005.09.038

[10] Chohan, Z.H., Pervez, H., Rauf, A., Khalid, K.M. and Supuran, C.T. (2006) Antibacterial Cobalt(II), Copper(II), Nickel(II) and Zinc(II) Complexes of Mercaptothiadiazole-Derived Furanyl, Thienyl, Pyrrolyl, Salicylyl and Pyridinyl Schiff Bases. Journal of Enzyme Inhibition and Medicinal Chemistry, 21, 193-201. http://dx.doi.org/10.1080/14756360500397505

[11] Joseph, J., Nagashri, K. and Boomadevi Janaki, G. (2012) Novel Metal Based Anti-Tuberculosis Agent: Synthesis, Characterization, Catalytic and Pharmacological Activities of Copper Complexes. European Journal of Medicinal Chemistry, 49, 151-163. http://dx.doi.org/10.1016/j.ejmech.2012.01.006

[12] Yuan, R., Xiong, R., Chen, Z., Zhang, P., Ju, H., Dai, Z., Guo, Z., Fun, H. and You, X. (2001) Crystal Structure of Zinc(II) 2-Sulfanilamidopyrimidine: A Widely Used Topical Burn Drug. Journal of the Chemical Society, Dalton Transactions, 6, 774-776. http://dx.doi.org/10.1039/b100901j

[13] Yang, L., Yang, X., Liu, J., Li, Y., Lou, Q. and Liu, Q.J. (2003) Synthesis, Characterization and Susceptibility of Bacteria against Sulfamethoxydiazine Complexes of Copper(II), Zinc(II), Nickel(II), Cadmium(II), Chromium(III) and Iron(III). Journal of Coordination Chemistry, 56, 1131-1139. http://dx.doi.org/10.1080/00958970310001596746a

[14] Torre, M.H., Calvo, S., Pardo, H. and Mombrú, A. (2005) Synthesis, Spectroscopic Characterization and Crystal Structure of Disulfamethoxazole Diaquo Ni(II) Monohydrate. Journal of Coordination Chemistry, 58, 513-520. http://dx.doi.org/10.1080/00958970500037516

[15] Macías, B., Villa, M.V., García, I., Castiñeiras, A., Borrás, J. and Cejudo-Marin, R. (2003) Copper Complexes with Sulfonamides: Crystal Structure and Interaction with pUC18 Plasmid and Hydrogen Peroxide. Inorganica Chimica Acta, 342, 241-246. http://dx.doi.org/10.1016/S0020-1693(02)01167-2

[16] Maurya, R.C., pandey, A. and Sutradhar, D. (2004) Synthesis, Magnetic and Spectral Studies of Some Novel Binuclear Dioxomolybdenum(VI) Chelates Involving Schiff Bases Derived from Sulpha Drugs and 4-Benzoyl-3-methyl-1phenyl-2-pyrazolin-5-one. Indian Journal of Chemistry, 43A, 763-768. 
[17] Maurya, R.C. and Rajpu, S.J. (2006) Oxovanadium(IV) Complexes of Bioinorganic and Medicinal Relevance: Synthesis, Characterization and 3D Molecular Modeling and Analysis of Some Sulfa Oxovanadium(IV) Complexes Involving the O, N-Donor Environment of Pyrazolone-Based Drug Schiff Bases. Journal of Molecular Structure, 79, 24-34. http://dx.doi.org/10.1016/j.molstruc.2006.01.031

[18] Maurya, R.C., Patel, P. and Rajput, S. (2003) Synthesis and Characterization of Mixed Ligand Complexes of Cu(II), Ni (II), Co(II), Zn(II), Sm(III), and U(VI) $\mathrm{O}_{2}$, with a Schiff Base Derived from the Sulfa Drug Sulfamerazine and 2, 2'Bipyridine. Synthesis and Reactivity in Inorganic and Metal-Organic Chemistry, 33, 801-816.

[19] Cartwright, A.J., Jones, P., Wolff, J.C. and Evans, E.H. (2005) Detection of Phosphorus Tagged Carboxylic Acids Using HPLC-SF-ICP-MS. Journal of Analytical Atomic Spectrometry, 20, 75-80. http://dx.doi.org/10.1039/b415962d

[20] Agarwal, R.K., Prakash, B., Kumar, V. and Khan, A.A. (2007) Synthesis, Physico-Chemical and Thermal Characteristics of Seven and Ten Coordinated Complexes of Trivalent Lanthanides Derived from 4[N-(cinnamalidene)amino]antipyrine Semicarbazone and Diphenyl Sulfoxide. Journal of the Iranian Chemical Society, 4, 114-125. http://dx.doi.org/10.1007/BF03245809

[21] Mapari, A.K. and Mangaonka, K.V. (2011) Synthesis, Characterization and Antimicrobial Activity of Mixed Schiff Base Ligand Complexes of Transition Metal(II) Ions. International Journal of ChemTech Research, 3, 477-482.

[22] Gunasekaran, S. and Uthra, D. (2008) Vibrational Spectra and Qualitative Analysis of Albendazole and Mebendazole. Asian Journal of Chemistry, 20, 6310-6324.

[23] Neelakantan, M.A., Marriappan, S.S., Dharmaraja, J., Jeyakumar, T. and Muthukumaranc, K. (2008) Spectral, XRD, SEM and Biological Activities of Transition Metal Complexes of Polydentate Ligands Containing Thiazole Moiety. Spectrochimica Acta Part A, 71, 628-635. http://dx.doi.org/10.1016/j.saa.2008.01.023

[24] Karthikeyan, G., Mohanraj, K., Elango, K.P. and Girishkumar, K. (2006) Synthesis and Spectral Characterization of Lanthanide Complexes with Sulfamethoxazoleand Their Antibacterial Activity. Russian Journal of Coordination Chemistry, 32, 380-385. http://dx.doi.org/10.1134/S1070328406050113

[25] Nejo, A.A., Kolawole, G.A., Opoku, A.R., Muller, C. and Wolowska, J. (2009) Synthesis, Characterization, and Insulin-Enhancing Studies of Unsymmetrical Tetradentate Schiff-Base Complexes of Oxovanadium(IV). Journal of Coordination Chemistry, 62, 3411-3424. http://dx.doi.org/10.1080/00958970903104327

[26] Khazaei, A.K., Zolfigol, M.A. and Abedian, N. (2001) Synthesis and Characterization of Poly[4-imino(N-4-ethylbenzoate) benzene pstyrenesulphonate] and the Investigation on Polymer Ability for Drug Release. Iranian Polymer Journal, 10, 59.

[27] Ying, L.M., Zhi, H.P., Cheng, Z.J., Yi, L. and Xi, X.K. (2004) Study on Syntheses and Anti-Bacterial Activities of Some New Transition Metal Complexes with Schiff Base Ligand Containing Pyridine and Amide Moieties. Chinese Journal of Chemistry, 22, 162-166.

[28] El-Gahami, M.A. and Abdalla, E.M. (2003) Synthetic and Spectroscopic Studies of Polymeric Metal Complexes Involving 1,4-[5-Disulphonyl-8-hydroxyquinoline]Piperazine. Journal of Inorganic and Organometallic Polymers and Materials, 13, 41-48. http://dx.doi.org/10.1023/A:1022900914224

[29] Abd Elwahab, Z.H., Mashaly, M.M. and Faheim, A.A. (2005) Synthesis and Characterization of Cobalt(II), Cerium(III), and Dioxouranium(VI) Complexes of 2,3-Dimethyl-1-phenyl-4-salicylidene-3-pyrazolin-5-one Mixed Ligand Complexes, Pyrolytic Products, and Biological Activities. Chemical Papers, 59, 25-36.

[30] Blasco, F., Perello, L., Latorre, J., Borra, J. and Garcia Granda, S. (1996) Cobalt(II), Nickel(II), and Copper(II) Complexes of Sulfanilamide Derivatives: Synthesis, Spectroscopic Studies, and Antibacterial Activity. Crystal Structure of [Co(sulfacetamide) $)_{2}$ (NCS)]. Journal of Inorganic Biochemistry, 61, 143-154. http://dx.doi.org/10.1016/0162-0134(95)00053-4

[31] Dobrzanska, L., Wrzeszcz, G. and Grodzick, I.A. (2000) Synthesis and Properties of Thiocyanato-Bridged ChromiumIII)-Copper(II) Hydroxo Complexes. Polish Journal of Chemistry, 74, 1017-1021.

[32] Zhu, D.R., Song, Y.X., Zhang, Y.Y., Raj, S.S.S., Fun, H.K. and You, X.Z. (2000) Syntheses, Crystal Structures and Properties of the Novel Co(II) and Ni(II) Complexes with 4-(p-Methylphenyl)-3,5-bis(pyridin-2-yl)-1,2,4-triazole. Polyhedron, 19, 2019-2025. http://dx.doi.org/10.1016/s0277-5387(00)00501-5

[33] Jain, M.C., Shrivastava, A.K. and Jain, P.C. (1977) Some Tetragonally Distorted Copper(II) Complexes of 4-Benzylamidothiosemicarbapzide and Its Thiosemicarbazone. Inorganica Chimica Acta, 23, 199-203. http://dx.doi.org/10.1016/S0020-1693(00)94761-3

[34] Canpolat, E., Yciazi, A. and Kaya, M. (2006) Synthesis and Characterization of Mononuclear Cobalt(II), Nickel(II), Copper(II), Zinc(II), Cadmium(II) and Dinuclear Uranyl(VI) Complexes with $N, N$-Bis(2-\{[(2,2-dimethyl-1,3-dioxolan4-yl)methyl]amino\}butyl)N',N'-Dihydroxyethanediimidamide. Transition Metal Chemistry, 31, 653-657. http://dx.doi.org/10.1007/s11243-006-0042-0

[35] Erdem, E.E., Sari, Y., Arslan, R.K. and Kabay, N. (2009) Synthesis and Characterization of Azo-Linked Schiff Bases 
and Their Nickel(II), Copper(II), and Zinc(II) Complexes. Transition Metal Chemistry, 34, 167-174. http://dx.doi.org/10.1007/s11243-008-9173-9

[36] Figgis, B.N. (1976) Introduction to Ligand Fields. Wiley, New York, 98.

[37] Abd El-Wahab, Z.H., Mashaly, M.M., Salman, A.A., El Shetary, B.A. and Faheim, A.A. (2004) Co(II), Ce(III) and $\mathrm{UO}_{2}$ (VI) Bis-Salicylatothiosemicarbazide Complexes: Binary and Ternary Complexes, Thermal Studies and Antimicrobial Activity. Spectrochimica Acta Part A, 60, 2861-2873. http://dx.doi.org/10.1016/j.saa.2004.01.021

[38] Alaghaz, A.M.A. and Ammar, R.A. (2010) New Dimeric Cyclodiphosph(V)azane Complexes of Cr(III), Co(II), Ni(II), $\mathrm{Cu}(\mathrm{II})$, and Zn(II): Preparation, Characterization and Biological Activity Studies. European Journal of Medicinal Chemistry, 45, 1314-1322. http://dx.doi.org/10.1016/j.ejmech.2009.12.008

[39] Singh, H.L., Singh, J.B. and Sharma, K.P. (2012) Synthetic, Structural, and Antimicrobial Studies of Organotin(IV) Complexes of Semicarbazone, Thiosemicarbazone Derived from 4-Hydroxy-3-methoxybenzaldehyde. Research on Chemical Intermediates, 38, 53-65. http://dx.doi.org/10.1007/s11164-011-0325-8

[40] Gehad, G.M., Mohamed, M.O. and Ahmed, M.H. (2006) Metal Complexes of Schiff Bases: Preparation Characterization, and Biological Activity. Turkish Journal of Chemistry, 30, 361-382.

[41] Wright, J.B., Lam, K., Hansen, D. and Burrell, R.E. (1999) Efficacy of Topical Silver against Fungal Burn Wound Pathogens. American Journal of Infection Control, 27, 344-350. http://dx.doi.org/10.1016/S0196-6553(99)70055-6 